\title{
DAKWAH MELALUI FILM ANALISIS SEMIOTIKA PESAN DAKWAH DALAM FILM "SANG KIAI" KARYA RAKO PRIJANTO
}

\author{
Haris Supiandi \\ Program Studi Penciptaan Seni Videografi \\ Pascasarjana Institut Seni Indonesia, Yogyakarta \\ email : supiandiwork@gmail.com \\ Diterima : 18 Agustus 2020. Disetujui : $2 \underline{5}$ November 2020. Dipublikasikan : 1 Desember 2020 \\ cC) (7) $\begin{aligned} & \text { (C) } 2020-\text { DESKOVI Universitas Maarif Hasyim Latif. Ini adalah artikel dengan akses } \\ & \text { terbuka di bawah lisensi CC BY } 4.0 \text { (https://creativecommons.org/licenses/by/4.0/) }\end{aligned}$
}

\begin{abstract}
ABSTRAK
Tujuan dari penelitian ini secara umum untuk mengetahui bagaimana dakwah melalui film di dalam film "Sang Kiai” karya Rako Prijanto melalui semiotika Roland Barthes. Berdasarkan pada analisis yang dilakukan, maka peneliti menyimpulkan bahwa film ini syarat dengan pesan dakwahnya, di mana proses dakwah yang terjadi di dalam film ini ialah tentang suri teladan seorang kiai Hasyim Asyari yang begitu dikagumi oleh para santri pondok pesantren Tebu Ireng, sahabat dan keluarganya.; (1) terdapat tiga pesan dakwah dalam film "Sang Kiai" karya Rako Prijanto yakni; pesan akidah, pesan akhlak dan pesan syariat. (2) dakwah dalam film "Sang Kiai" dikemas dengan menampilkan karakter-karakter dialog yang sangat menggugah dan penuh pesan bermakna hubungan antar sesama manusia dan hubungan kepada Allah SWT, dan tidak terlepas dari nilai-nilai nasionalisme. (3) simbolsimbol yang mengandung kaidah-kaidah yang Islami baik itu dari cara berpakaian, tutur kata, sikap yang sopan santun, hormat kepada orang tua dan guru, menjaga ibadah serta berjihad di jalan Allah SWT.
\end{abstract}

Kata Kunci: pesan dakwah, film, semiotika.

\section{ABSTRACT}

The purpose of this research in general is to study how da'wah through the film in the film "The Kiai" by Rako Prijanto through the semiotics of Roland Barthes. Based on the analysis conducted, the researcher concludes that this film has the message of da'wah, where the da'wah process that occurs in this film is about the example of a Kiai Hasyim Asyari who is highly admired by Tebu Ireng boarding school students, friends, and his family. ; (1) There are three da'wah messages in the film "Sang Kiai" by Rako Prijanto, namely : a) aqeedah message, the moral messages, \& sharia messages. (2) Da'wah in the film "The Kiai" is packaged by displaying characters of dialogue that are very evocative and full of meaningful messages of relationships between human beings and relationships to Allah SWT, and are inseparable from the values of nationalism. (3) Symbols that display Islamic rules both from the way of dress, speech, polite attitude, respect to parents and teachers, maintain worship, and strive in the way of Allah SWT.

Keywords: da'wah message, film, semiotics.

\section{PENDAHULUAN}

Berdakwah melalui media film adalah salah satu cara berdakwah melalui media, melihat sekarang ini banyak sekali film-film layar lebar yang bergenre religi bermunculan di muka masyarakat, dan juga di dalam film-film layar lebar tersebut tersirat sebuah pesan dakwah, baik itu dari percakapan ataupun tingkah laku yang ada di dalam film tersebut. Menurut Toha Yahya Umar (1967: 1), dakwah adalah mengajak manusia dengan cara bijaksana ke jalan yang benar sesuai dengan perintah Tuhan, untuk keselamatan dan kebahagiaan dunia akhirat.

Definisi dakwah di dalam islam adalah sebagai kegiatan mengajak, mendorong, dan memotivasi orang lain berdasarkan bashirah untuk meniti jalan Allah serta berjuang bersama meningkatkan agama-Nya. Kata mengajak, memotivasi dan mendorong adalah kegiatan dakwah dalam ruang lingkup tabligh. Kata bashirah untuk menunjukkan dakwah itu harus dengan ilmu dan perencanaan yang baik. Kalimat meniti jalan Allah untuk menunjukkan tujuan dakwah yaitu mardhatillah. Kalimat istiqamah dijalan-Nya untuk menunjukkan dakwah itu harus 
berkesinambungan. Sedangkan kalimat berjuang bersama meninggikan agama Allah untuk menunjukkan dakwah bukan untuk menciptakan kesalehan pribadi. Untuk mewujudkan masyarakat yang saleh tidak bisa dilakukan sendiri-sendiri, tetapi harus bersama. (Muhammad Ali Aziz, 2004:4).

Secara sederhana pengemasan dakwah yang dimaksud adalah menyangkut persoalan bagaimana pesan dakwah ditata dan dikelola (Ibrahim, $2015: 12$ ). Pengemasan menurut kamus bahasa Indonesia yang berarti: 1) tata atau penataan; 2). Rapi atau penyusunan menjadi rapi dan teratur ; 3). Pemolaan, pengelolaan atau membuat format tertentu sehingga menjadi lebih baik, rapi dan teratur.

Di tengah perkembangan yang pesat ini, film yang disajikan di layar lebar telah menawarkan berbagai warna sedemikian rupa, tentunya disesuaikan dengan fenomena yang sedang terjadi pada masyarakat atau mencoba menguak sejarah yang terdahulu. Di antaranya keanekaragaman film yang disajikan di layar lebar yang bersifat pesan dakwah begitu membangun dan sesuai dengan kejadian yang sesungguhnya di masyarakat, salah satunya yakni film Sang Kiai karya Rako Prijanto.

Film dimasukkan ke dalam kelompok Komunikasi Massa. Selain mengandung aspek hiburan, juga memuat pesan edukatif. Namun aspek sosial kontrolnya tidak sekuat pada surat kabar atau majalah serta televisi memang menyiarkan berita berdasarkan fakta yang terjadi (Mafri Amir, 1999: 27). Pada dasarnya film dapat dikelompokkan ke dalam dua pembagian dasar, yaitu kategori film cerita dan tidak cerita. Pendapat lain menggolongkan menjadi film fiksi dan tidak fiksi. Film cerita adalah film yang diproduksi berdasarkan cerita yang dikarang, dan dimainkan oleh aktor dan aktris. Pada umumnya film cerita bersifat komersial, artinya dipertunjukkan di bioskop dengan harga karcis tertentu atau diputar di televisi dengan dukungan sponsor iklan tertentu. Film tidak cerita adalah film yang mengambil kenyataan sebagai subyeknya, yaitu merekam kenyataan dari pada fiksi tentang kenyataan. (Sumarno, 1996:10).

Film yang di sutradarai Rako Prijanto ini mencoba menawarkan sebuah pesan dan pendekatan berbeda dari film-film yang beredar saat ini yang lebih mendominasi oleh film-film yang bertemakan cinta dan horor. Di mana film Sang Kiai ini mempunyai berbagai macam pesan salah satunya pesan dakwah serta gambaran perjuangan umat Islam melawan penjajah demi mempertahankan NKRI (Negara Kesatuan Republik Indonesia).

Film yang menceritakan tentang seorang tokoh perjuangan di pesantren Tebu Ireng Jombang Nahdatul Ulama ( NU ) yaitu KH. Hasyim Asyari kakek dari KH. Abdurahman Wahid (Gusdur), ia adalah seorang tokoh perjuangan pesantren Tebu Ireng Jombang, Jawa Timur. Film ini diperankan oleh beberapa artis Indonesia seperti Ikra Negara, Christine Hakim, Agus Kuncoro, Adipati Dolken, Meryza
Batubara, Norman Akuwen, Dimas Aditya dan Suzuki Naburo.

Film "Sang Kiai" ini akan dianalisis dengan pendekatan semiotika Roland Barthes, yang mana pada dasarnya manusia hidup dipenuhi dengan tanda-tanda, baik tanda-tanda alam maupun tanda-tanda buatan. Dalam berkomunikasi, manusia 'dihujani' oleh tandatanda, di sinilah semiotika menjadi daya tarik utama untuk dipelajari, dengan semiotika kita dapat mengungkapkan makna-makna baik yang tersirat maupun yang tersurat. Untuk dapat menyibak tabir tanda, tentu diperlukan keahlian seseorang, mempelajari semiotika semangat membatu kita dalam menemukan makna dari pesan-pesan yang disampaikan oleh orang lain, baik yang disengaja maupun tidak.

Penelitian ini memfokuskan pada sebuah kajian tanda dalam sebuah film. Berkaitan dalam hal tersebut, maka peneliti menggunakan analisis semiotika Roland Barthes. Teori Barthes menjelaskan bahwa hakikat penanda sama saja dengan pertanda, yaitu secara murni adalah relatum yang batasannya tidak dapat dipisahkan. Satu-satunya perbedaannya dengan pertanda adalah bahwa penanda merupakan sebuah mediator, suatu hal yang perlu untuknya. Sebagai mediator, substansi merupakan materi seperti suara, obyek, imaji (Kurniawan, 2001:58).

Serta di dalam sebuah film akan memuat pesan-pesan dakwah, pesan adalah pernyataan sebagai panduan dan perasaan, dapat berupa ide, informasi, keluhan, keyakinan, imbauan, anjuran dan sebagainya. Pesan merupakan pernyataan yang didukung oleh lambang atau simbol. Pesan itu sendiri memiliki makna yang signifikan yaitu suatu peristiwa simbolis yang menyatakan akan penafsiran tentang kejadian fisik, baik oleh penutur maupun mitra tutur. Kejadian ini bisa disebut sebagai proses penafsiran penyandian pengalihan sandi yang memberikan nilai pesan simbol.

Menurut Sam Abede Pareno (2002) bahwa pesan sebagai penafsiran lambang atau stimuli. Sebagai suatu proses penafsiran sangat tergantung pada penjelasan psikologis tentang komunikasi manusia. Selain itu, pesan mencerminkan keadilan internal individu yakni perilaku, dalam bentuk tertentu. Suatu manifestasi yang mencuat keluar dari konsep kotak hitam tentang sikap, keyakinan, nilai, Citra, emosi dan sebagainya.

Sehingga bila dipahami semiotika yang dimaksud Barthes menyebut denotasi (penanda), yaitu makna paling nyata dari tanda. Konotasi (pertanda) adalah istilah yang digunakan Barthes untuk menunjukkan signifikasi tahap kedua. Hal ini menggambarkan interaksi yang terjadi ketika tanda bertemu dengan perasaan atau emosi dari pembicara serta nilai-nilai dari kebudayaan. Konotasi mempunyai makna yang subyektif atau paling tidak inter-subyektif. Dengan kata lain, denotasi adalah apa yang telah digambarkan tanda terhadap sebuah obyek, sedangkan konotasi adalah bagaimana menggambarkannya. Inilah yang melatar belakangi penulis untuk mengangkat judul "Dakwah Melalui Film Analisis Semiotika Pesan 
Dakwah Dalam Film "Sang Kiai" Karya Rako Prijanto".

\section{METODE PENELITIAN}

Metode yang digunakan untuk menganalisis data yang telah diperoleh, menggunakan analisis semiotika. Adapun analisis semiotika yang digunakan adalah semiotika Roland Barthes. Studi semiotika mengambil fokus penelitian pada seputar tanda baik tanda verbal ataupun non - verbal. Tanda verbal meliputi ucapan lisan atau kata-kata sedangkan non verbal meliputi ekspresi wajah, gerakan tubuh dan lain sebagainya yang tidak bersifat oral. Dalam kerangka Barthes, konotasi identik dengan operasi ideologi yang disebutnya mitos dan berfungsi untuk mengungkapkan dan memberikan pembenaran bagi nilai-nilai dominan yang berlaku dalam suatu periode tertentu (Nawiroh Vera, 2014:28). Fokus perhatian Barthes lebih tertuju kepada gagasan tentang signifikasi dua tahap (two order of signification) seperti pada gambar di bawah ini (Alex Sobur, 2012:127).

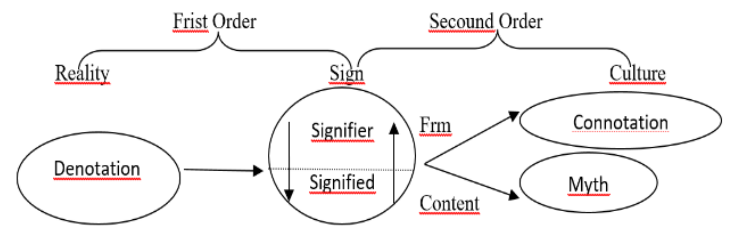

Gambar 1. Sumber: Alex Sobur, Analisis Teks Media, 2004, hlm. 127

Untuk menafsirkan sebuah tanda Barthes mengemukakan sebuah teori semiotika atau proses signifikasi. Signifikasi merupakan suatu proses yang memadukan penanda dan pertanda sehingga menghasilkan tanda. Sebagai mana terlihat dalam peta tersebut bahwa tanda denotatif (3) terdiri atas penanda (1) dan pertanda (2). Akan tetapi dalam saat yang bersamaan tanda denotatif juga menjadi pertanda konotatif. Dengan kata lain hal tersebut merupakan unsur material. Yang ikut menjadi dasar terbentuknya makna konotasi. Makna konotatif menurut Barthes biasanya mengacu pada makna yang menempel pada suatu tanda karena sejarah pemakaiannya, tidak hanya pada konteks. Adapun tahapan dalam penelitian adalah

1. Mengidentifikasi pesan dakwah dalam film "Sang Kiai"

2. Setelah mengidentifikasi barulah data tersebut dapat di kategorikan sesuai dengan akidah, akhlak dan Syariah

3. Menganalisis setiap tanda tersebut sesuai dengan teori Roland Barthes yakni mengintervensi data penanda serta pertandanya

4. Data yang sudah dianalisis selanjutnya akan dideskripsikan pesan dakwah berdasarkan makna dari penanda dan pertanda

5. Sehingga barulah data tersebut dapat disimpulkan secara umum sesuai dengan fokus masalah dari penelitian ini yakni pesan dakwah di film, pengemasan pesan dakwah, dan simbol-simbol dalam film

\section{HASIL DAN PEMBAHASAN}

Hasil dari identifikasi yang dilakukan dalam film Sang Kiai karya Rako Prijanto, ditemukan ada 16 materi akidah, 54 materi akhlak dan 60 materi syariat, data-data tersebut peneliti paparkan berdasarkan mengidentifikasi film Sang Kiai secara keseluruhan dan berulang dengan menyiapkan materi-materi dakwah. Memfokuskan penentuan materi dakwah yang telah disiapkan, kemudian membaginya sesuai dengan materi dakwah yakni akidah, akhlak dan Syariah.

\section{Pesan Akidah}

Menjadi acuan dari peneliti dalam memaparkan data materi aqidah dalam film Sang Kiai ini tidak hanya terhadap masalah yang wajib diimani, seperti iman kepada Allah, kepada Malaikat Allah, Rasul Allah, Kitab-Kitab Allah, Hari Akhir dan Takdir Allah. Mengesakan Allah dalam ibadah, yakni beribadah hanya kepada Allah dan karena-Nya semata, mengesakan Allah dalam perbuatan-Nya, yakni mengimani dan meyakini bahwa hanya Allah yang mencipta, menguasai dan mengatur alam semesta ini serta mengesakan Allah dalam asma dan sifat-Nya, artinya mengimani bahwa tidak ada makhluk yang serupa dengan Allah, dalam dzat, asma maupun sifat. tetapi juga meliputi masalah yang dilarang sebagai lawannya, misalnya syirik, (menyekutukan Allah SWT) dan lain-lain.

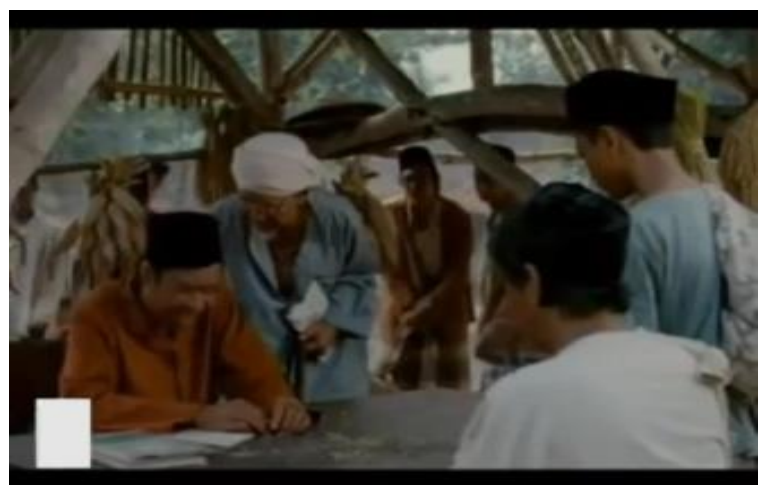

Gambar 2. Sumber : Hasil tangkapan layar dari film "Sang Kiai"

Dialog :

KH. Hasyim Asyari : "Allah itu... sebaik-baik maha pemberi rezeki".

Hamid : "iya Kiai"

KH. Hasyim Asyari : "bapak, anak bapak diterima menjadi santri di sini"

Pesan :

Percaya bahwa Allah SWT maha pemberi rezeki.

Penanda :

Gambar Kiai Hasyim Asyari terlihat berbicara dengan Hamid, yang terkejut dengan kedatangan kiai.

Pertanda : 
Hamid menolak keras saat seorang orang tua calon santri menyatakan tidak punya hasil bumi. Hamid menyatakan, jika tidak ada hasil bumi. Santri mau makan apa. Namun, kedatangan KH. Hasyim Asyari dengan mengucapkan bahwa Allah SWT maha pemberi rezeki.

Kalimat kiai yang mengatakan bahwa Allah adalah maha pemberi rezeki, meyakinkan Hamid dan semua orang tua dan wali calon santri, seperti di dialog

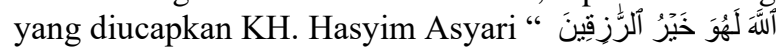
Allah itu... sebaik - baik maha pemberi rezeki" maknanya jika Allah itu sebaik-baiknya maha pemberi rezeki ungkapan kiai tersebut dibisikkan kiai dekat telinga Hamid dan disaksikan oleh santri dan orang tua dan wali calon santri Hal ini, tentu saja menegaskan jika ada ikhtiar dan doa, rezeki pasti datang, keyakinan seorang muslim kepada Allah SWT.

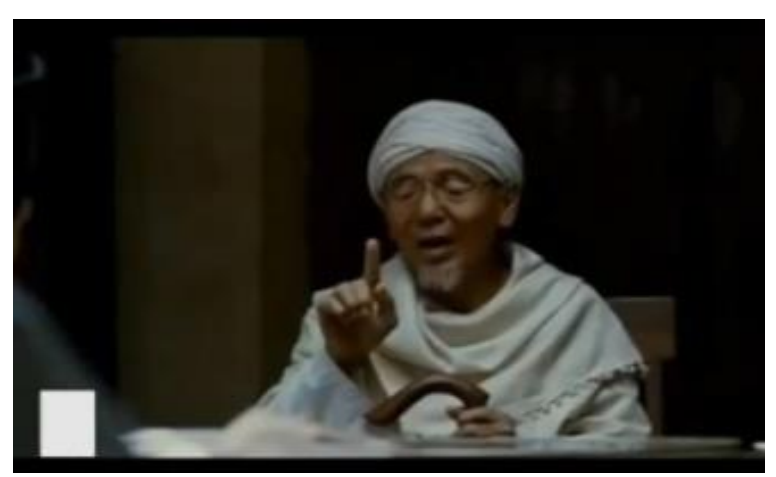

Gambar 3. Sumber : Hasil tangkapan layar dari film "Sang Kiai"

\section{Dialog :}

KH. Hasyim Asyari : "dalam hidup ini ada hal-hal yang bisa kita bicarakan, bahkan bisa kita kompromikan, tapi kalau sudah menyangkut soal akidah itu tidak bisa di ganggu gugat, kita membungkukkan badan di dalam shalat, itu semata-mata karena Allah SWT, Lillahitaala bukan karena kita dipaksa oleh manusia untuk menyembah apa-apa yang mereka sembah, lakum dinnukum walyadin".

Pesan :

Beriman kepada Allah SWT, dan tidak ada kompromi untuk masalah akidah atau iman.

Penanda :

KH.Hasyim Asyari mengangkat telunjuknya tangannya menandakan jika $\mathrm{KH}$ tengah membicarakan hal yang serius.

Pertanda :

KH. Hasyim Asyari datang menjelaskan dengan gamblang dan nada yang tegas, jika sudah mengenai akidah, maka tidak ada yang di kompromikan, karena menyangkut dengan keyakinan kepada Allah.

Scene ini berkaitan dengan akidah ialah pada saat wajah tegas kiai menolak untuk melakukan sekirei, saat ia hendak ditangkap oleh tentara Jepang di hadapan anak-anaknya dan para santri pondok pesantren Tebu Ireng. Dialog KH. Hasyim Asyari : "saya tidak tahu apa-apa tentang cukir, tapi saya tidak akan mau melakukan sekirei, karena itu hukumnya haram". Jelas sekali jika menyekutukan Allah itu, haram. Termasuk perintah sekirei dari tentara Jepang yakni menyembah dewa matahari, karena di dalam agama Islam hanya Allah yang wajib disembah dan hanya kepada Allah meminta pertolongan.

\section{Pesan Akhlak}

Menurut Sahilun Nasir (1991), akhlak dalam islam berkisar pada yaitu:

1. Tujuan hidup setiap muslim adalah menghambakan dirinya kepada Allah untuk mencapai keridaan-Nya, hidup sejahtera lahir dan batin dan dalam kehidupan masa kini maupun masa yang akan datang.

2. Dengan keyakinannya terhadap kebenaran wahyu Allah SWT dan Rasul-Nya, membawa konsekuensi logis, sebagai standar dan pedoman utama bagi setiap muslim. Ia memberi sanksi terhadap islam dalam kecintaan dan kekuatannya kepada Allah, tanpa adanya perasaan tekanantekanan dari luar.

3. Keyakinan akan hari kemudian/pembalasan, mendorong manusia berbuat baik dan dan berusaha menjadi sebaik mungkin dengan segala pengabdiannya kepada Allah.

4. Islam tidak (menerima) islam baru yang bertentangan dengan ajaran dan jiwa islam, berdasarkan dari Al-Quran dan Al-Hadist diinterpretasikan oleh para ulama mujtahid.

5. Ajaran akhlak islam meliputi segala segi hidup dan kehidupan manusia berdasarkan atas kebaikan dan bebas dari segala kejahatan. Islam tidak hanya mengajarkan tetapi menegakkannya, dengan janji dan saksi Ilahi yang maha Adil. Tuntunan islam sesuai dengan bisikan hati nurani yang menurut kodratnya cenderung kepada kebaikan dan membenci keburukan.

Yang menjadi fokus dalam penelitian yakni melihat dari sisi akhlak terhadap manusia dengan melakukan cara yang sama dalam menentukan materi akhlak di film Sang Kiai ini.

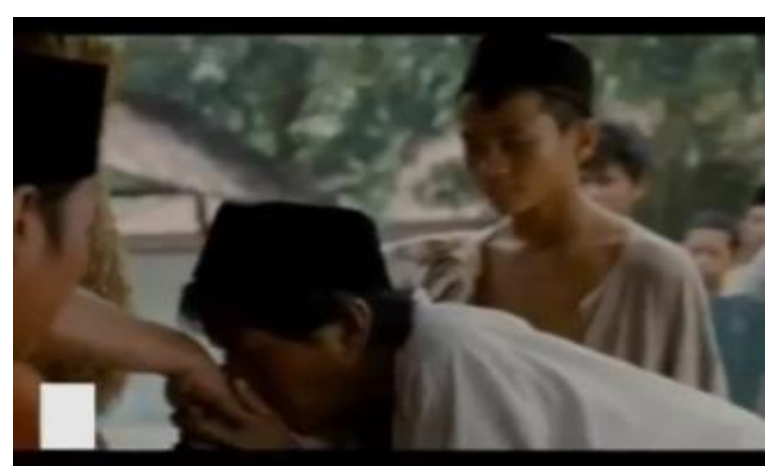

Gambar 4. Sumber : Hasil tangkapan layar dari film "Sang Kiai"

Dialog :

Orang Tua Santri : "matur suwun hadratussyaikh" 
Pesan :

Adab Menghormati ulama, guru dan cara berterima kasih.

Penanda :

Salah satu orang tua calon santri tebu ireng sedang mencium tangan Kiai.

Pertanda :

Orang tua calon santri pesantren tebu ireng berterima kasih kepada kiai Hasyim Asyari yang telah menerima anak nya untuk nyantri diponpes Tebu Ireng dengan menyalami tangan kiai.

Seperti di dalam scene pada saat salah satu orang tua calon santri tebu ireng sedang mencium tangan Kiai, dialognya ialah Orang Tua Santri :"matur suwun hadratussyaikh". Maknanya ialah mencium tangan seorang yang lebih tinggi ilmunya atau lebih tua dari kita adalah sebagai pertanda menghormati orang tersebut, dengan derajat KH Hasyim Asyari yang di gelar Hadratussyaikh, layak bagi seorang untuk menghormatinya, terlebih dengan sikap kiai yang bersahaja, tanpa memilih kaya atau miskin untuk belajar di pesantrennya.

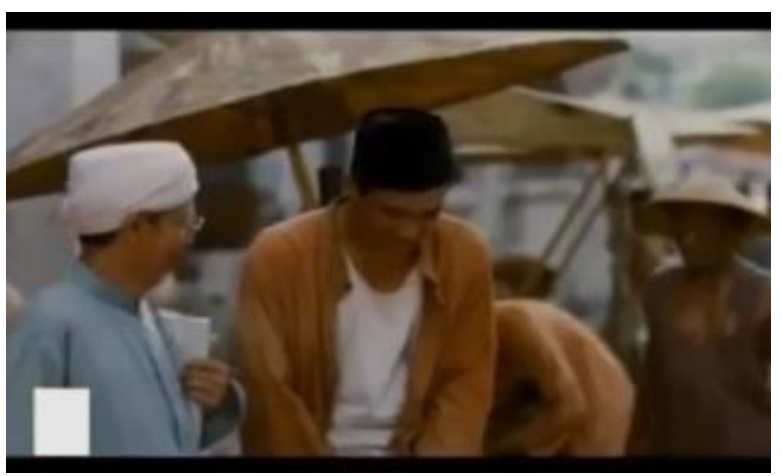

Gambar 5. Sumber : Hasil tangkapan layar dari film "Sang Kiai"

Dialog :

KH. Hasyim Asyari : “ ooo anaknya Muhidin, besok kalau ada waktu kita silaturrahim ke rumahnya Muhidin, melamar anaknya".

Pesan :

Silaturahmi.

Penanda :

Kiai tengah bertanya kepada harun, tentang siapa wanita yang dilihat Harun.

Pertanda :

Harun yang sedikit malu-malu saat ditanya perempuan yang barusan dilihat Harun oleh kiai, dan kiai pun mengajak Harun untuk silaturahmi ke rumah sari perempuan yang dilihat Harun, untuk melamarnya langsung.

Lalu di scene pada saat Harun (Adipati Dolken) yang sedikit malu-malu saat ditanya perempuan yang barusan dilihat Harun oleh Kiai, dan Kiai pun mengajak Harun untuk silaturahmi ke rumah sari perempuan yang dilihat Harun, untuk melamarnya langsung. Dalam ajaran Islam bersilaturahmi antar sesama muslim dapat menambah rezeki dan memperpanjang umur sesuai dengan hadis Rasulullah : "Dari Anas bin Malik RA, bahwa Rasulullah SAW bersabda : "barang siapa yang ingin diluaskan rezekinya dan dipanjangkan umurnya (kebaikannya) maka bersilaturahmilah. ( HR. Al-Bukhari )". Serta di dalam Islam juga mengharuskan bagi seorang muslim bila menyukai lawan jenisnya maka dianjurkan untuk melaksanakan lamaran lalu menjalin pernikahan, bila merasa sudah mampu untuk membangun rumah tangga.

\section{Pesan Syariat}

Syariat adalah seluruh hukum dan perundangundangan yang terdapat dalam Islam, baik yang berhubungan manusia dengan Tuhan, maupun antar manusia sendiri (Samsul Munir Amin, 2009: 90). Syariah merupakan aturan yang harus diaplikasikan dalam kehidupan sehari-hari, karena Syariah yang mengatur hubungan manusia dengan Tuhan, dan hubungan manusia dengan manusia. Syariah meliputi:

1. Ibadah yang meliputi yaitu Thaharah (bersuci), Sholat, Zakat, Puasa dan Haji.

2. Muamalah yang meliputi yaitu Munakahat (hukum nikah), Waratsah (hukum waris), Muamalah (hukum jual beli), Jinayah (hukum pidana), Khilafah (hukum negara) dan Jihad (hukum peperangan dan perdamaian).

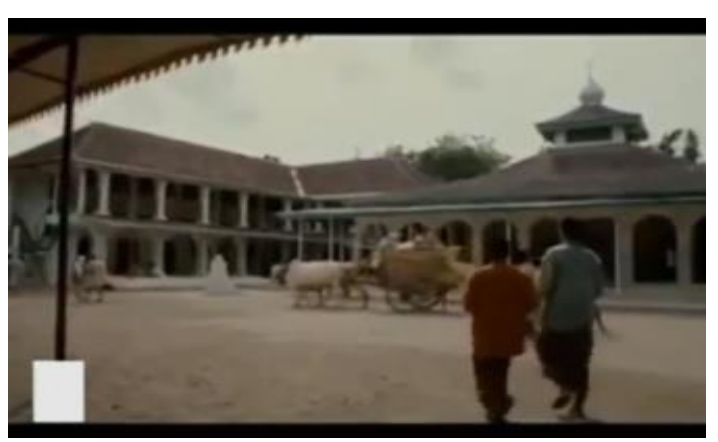

Gambar 6. Sumber : Hasil tangkapan layar dari film "Sang Kiai"

Dialog : tidak ada dialog

Pesan : Menutup aurat

Penanda :

Para santri pondok pesantren Tebuireng sedang menuju masjid.

Pertanda :

Para santri sedang menuju kemasjid, dengan menggunakan pakaian yang menutup aurat atau dengan menggunakan pakaian rapi dengan sarung dan kopiah.

Di scene para santri sedang menuju ke masjid, dengan menggunakan pakaian yang menutup aurat atau dengan menggunakan pakaian rapi dengan sarung dan kopiah, maknanya ketika hendak ke masjid seseorang mestilah menggunakan pakaian yang rapi, seperti bagi kaum laki-laki menggunakan sarung, baju muslim dan kopiah, seperti diadegan ini terlihat para santri sedang menuju masjid dengan pakaian yang menutup aurat, 
sesuai dengan perintah Allah SWT dalam QS Al-'Araf ayat 26 yang Artinya : "Hai anak Adam, Sesungguhnya Kami telah menurunkan kepadamu pakaian untuk menutup auratmu dan pakaian indah untuk perhiasan. dan pakaian takwa Itulah yang paling baik. yang demikian itu adalah sebahagian dari tanda-tanda kekuasaan Allah, Mudah-mudahan mereka selalu ingat".

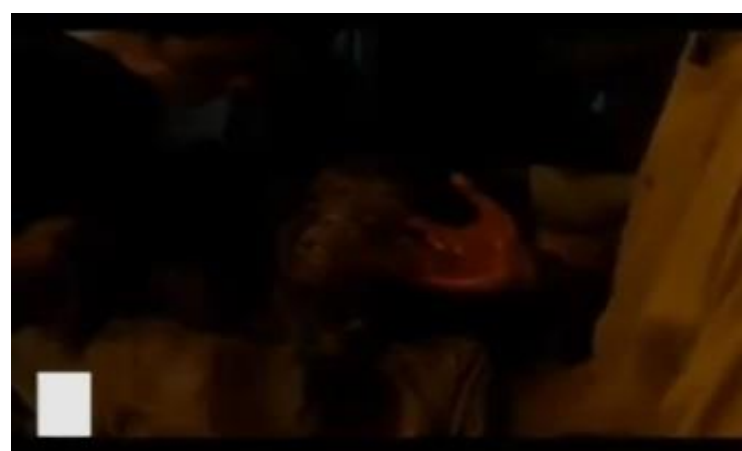

Gambar 7. Sumber : Hasil tangkapan layar dari film "Sang Kiai"

Dialog :

Para Santri : "Innalillahi wainnailahi rojiun".

Pesan :

Mengucap kalimat Istirja', saat mendapat sebuah musibah

Penanda :

Harun dan para santri mengucapkan kalimat istirja'

Pertanda :

Harun dan para santri yang lain mengucapkan kalimat istirja' (innalillahi wainnailaihi rojiun) kepada jenazah Khamid yang tewas ditembak oleh tentara Jepang

Adegan yang memperlihatkan Harun menangis saat tangannya menutup mata jenazah sahabatnya Khamid sambil ia mengucapkan kalimat istirja' sebagai bentuk bahwa kepercayaan bahwa segala sesuatu itu datang dari Allah dan akan kembali kepada Allah. Di dalam syariat Islam kalimat “Innalillahi Wainnailahi Rojiun” adalah sebagai tanda ucapan untuk orang yang terkena musibah, kalimat ini juga disebut kalimat istirja' .Umat Islam meyakini bahwa Allah adalah Esa yang memberikan dan Dia juga yang mengambil, Dia menguji umat manusia. Oleh karenanya, umat Islam menyerahkan diri kepada Tuhan dan bersyukur kepada Tuhan atas segala yang mereka terima. Pada masa yang sama, mereka bersabar dan menyebut ungkapan ini saat menerima cobaan atau musibah. Kemudian dalam syariat Islam, jika seorang Muslim ditimpa musibah, kemudian ia bersabar dan mengucapkan kalimat istirja' maka Allah akan memberikan pahala.

\section{Pesan Dakwah Dalam Film Sang Kiai}

Di dalam hasil pengamatan terhadap film Sang Kiai yang berdurasi 02:04:23 (2 jam 4 menit 23 detik) ini terdapat tiga pesan dakwah yakni pesan akidah, pesan akhlak dan pesan syariat. Untuk pesan akidah sendiri ada sebayak 13 visual, dari film ini pesan kaidah yang di temukan semuanya membahas tentang beriman kepada Allah SWT dan berjihad dijalan-Nya. Pesan akhlak sendiri terdapat 53 visual, yang mana di dalam penelitian ini didapati memiliki pesan tentang menghormati orang tua, menghormati guru, sopan santun saat bertamu, berperilaku baik antar suami dan istri, bersikap rendah hati.

Dan yang terakhir dari pesan dakwah penelitian ini ialah pesan syariat di dalam film Sang Kiai terdapat 54 visual, yang didapati pesan tentang berwudu, melaksanakan Shalat, menjawab salam dari seseorang, berpakaian menutup aurat, menafkahi istri, menahan hawa nafsu, berani menentang kemungkaran, mengurus mayat, berani melawan kemungkaran, menjaga hubungan baik antar sesama muslim, melaksanakan pernikahan, bersyukur kepada Allah SWT, berbakti kepada suami.

\section{Pengemasan Pesan Dakwah}

Dari sisi bentuk pengemasan pesan dakwah dalam film kiai mendapati bahwa dari tampilan film ini di kemas secara rapi dan disajikan sesuai dengan gambaran suasana pondok pesantren Tebu Ireng zaman dahulu, dan karakter pemain yang sangat mendalami peran mereka, ini dapat dilihat dari setiap pemotongan gambarnya saling berkaitan dan menampilkan karakter-karakter dialog yang sangat menggugah dan penuh pesan bermakna hubungan antar sesama manusia dan hubungan kepada Allah SWT, dan tidak terlepas dari nilai-nilai nasionalisme. Untuk isi dari film ini konten-kontennya hampir keseluruhan menceritakan bagaimana kiai Hasyim Asyari dalam menghadapi cobaan dengan sabar, membangun hubungan baik itu kepada santri, sahabat dan keluarganya, ia juga menjaga ibadahnya dalam keadaan apa pun saat sakit bahkan saat diancam untuk dibunuh.

\section{Simbol-Simbol Dalam Film}

Simbol-simbol yang terdapat di dalam film Sang Kiai ditemui, memakai pakaian yang menutup aurat, yang bukan muhrimnya dilarang berjumpa secara langsung, nada bicara kiai Hasyim Asyari yang rendah serta bersahaja menunjukkan sikap yang rendah hati, penyayang, sabar dan perilaku kiai yang taat kepada Allah SWT saat di dalam keadaan apa pun, tidak pernah suudzon kepada orang lain, tegas dalam melawan kemungkaran ini sesuai dengan kaidah agama Islam, terlepas dari para aktor tentara Jepang yang arogan dan kejam. Menandakan bahwa film ini banyak menampilkan kaidah-kaidah yang islami baik itu dari cara berpakaian, tutur kata, sikap yang sopan santun, hormat kepada orang tua dan guru, menjaga ibadah serta berjihad di jalan Allah SWT.

\section{KESIMPULAN}

Berdasarkan data-data yang telah dibahas maka dapat disimpulkan secara keseluruhan, bahwa dakwah melalui media film memiliki urgensi yang 
sangat besar dalam pengembangan dakwah seperti di dalam penelitian ini tentang dakwah dalam film Sang Kiai karya Rako Prijanto, film ini syarat dengan pesan dakwahnya, di mana proses dakwah yang terjadi di dalam film ini ialah tentang suri teladan seorang kiai Hasyim Asyari yang begitu dikagumi oleh para santri pondok pesantren Tebu Ireng, sahabat dan keluarganya. Baik itu tutur katanya yang sopan, sikapnya yang baik dalam memperlakukan anak-anaknya, istrinya dan santri-santrinya serta ketaatannya menjaga ibadah. Dan sikap kiai yang tegas dalam melawan penjajah, berjihad di jalan Allah.

\section{DAFTAR PUSTAKA}

Abede, Pareno Sam. 2005. Manajemen Berita antara Idealisme dan Realita. Surabaya, Papyrus.

A Nasir, Sahilun. 1991. Tinjauan Akhlak. Surabaya: Al Ikhlas.

Amin, Samsul Munir. 2009. Ilmu Dakwah. Jakarta. Amzah.
Amir, Mafri. 1999. Etika Komunikasi Massa Dalam Pandangan Islam. Jakarta. PT. Logos Wacana Ilmu.

Aziz, Mohammad Ali. 2004. Ilmu Dakwah. Jakarta. Kencana.

Departemen Agama RI. 2010. Al-Qur'an dan Tafsirnya. Jilid 10. Jakarta: Lentera Abadi.

Ibrahim. 2015. Dakwah Dalam Kemasan Media : Seri Kajian Komunikasi Penyiaran islam. Pontianak. IAIN Pontianak PRESS.

Kurniawan. 2001. Semiologi Roland Barthes. Magelang. Yayasan Indonesiatera.

Vera, Nawiroh. 2014. Semiotika dalam Riset Komunikasi. Bogor. Ghalia Indonesia.

Sobur Ale. 2003. Semiotika Komunikasi. Bandung. Remaja Rosdakarya.

Sumarno, Marselli. 1996. Dasar-dasar Apresiasi Film. Jakarta. Grasindo.

Umar, Toha Yahya. 1967. Ilmu Dakwah, Jakarta. Wijaya. 